\title{
New organotin(IV) chlorides derived from $N$-(2-hydroxyphenyl)aryloxy sulfamates. Synthesis, characterization and DSC investigation
}

\author{
ALI AKREMI ${ }^{\mathrm{a}, \mathrm{b}, *} \mathbb{D}$ and ADEL NOUBIGH ${ }^{\mathrm{a}, \mathrm{c}}$ \\ ${ }^{a}$ Department of Chemistry, Faculty of Science, Northern Border University, Arar 91431, \\ Kingdom of Saudi Arabia \\ ${ }^{b}$ Department of Chemistry, High Institute of Environmental Sciences and Technologies, Carthage University, \\ Borj Cedria, Tunisia \\ ${ }^{c}$ Laboratory of Physical Chemistry of Materials, Preparatory Institute for Scientific and Technical Studies of La \\ Marsa, 2070, Carthage University, Tunis, Tunisia \\ E-mail: akrimimi@gmail.com
}

MS received 4 September 2018; revised 17 December 2018; accepted 17 December 2018; published online 22 January 2019

\begin{abstract}
Three monomeric pentacoordinate organotin complexes were prepared by the reaction of dimethyltin dichloride with three $N$-(2-hydroxy)phenyl substituted aryloxy sulfamates in alkaline medium. The newly synthesized compounds were characterized on the basis of their infrared, CPMAS NMR, powder XRD diffraction and elemental analysis. The XRD powder analyses revealed a tetragonal system for two complexes, whereas the third one was crystallized in the hexagonal system. The thermal decomposition behavior of the synthesized complexes have been investigated and all the organotin compounds have a similar order of thermal stability.
\end{abstract}

Keywords. Penta-coordinate complex; organotin complexes; sulfamates; powder XRD; thermal stability .

\section{Introduction}

Sulfamates are found to be suitable intermediates for the design and development of various types of new molecules as therapeutic agents and for biological or pharmaceutical uses. Sulfamate derivatives have been identified as bioactive molecules which occupy a prominent place in medicinal chemistry because of their wide range therapeutic properties, such as anti-cancer, ${ }^{1-5}$ antibacterial, ${ }^{6-10}$ antioxidant, ${ }^{11,12}$ anti-HIV, ${ }^{13-15}$ anticonvulsant, ${ }^{16-19}$ antibiotic, ${ }^{13,20,21}$ antiobesity, ${ }^{22}$ diuretic, ${ }^{23,24}$ hypoglycemic, ${ }^{25}$ antithyroid, ${ }^{26}$ and anti-neuropathic pain ${ }^{27}$ activities. In addition, the electronic structure of $-\mathrm{SO}_{2} \mathrm{NH}_{2}$ group in sulfamates and related ligands was considered as moiety par excellence for designing potent carbonic anhydrases inhibitors (CAIs) because of its good chelating to the metal ion of the enzyme. ${ }^{28-32}$ Thus, complexation reaction of sulfonyl $\left(-\mathrm{SO}_{2} \mathrm{NH}_{2}\right)$ and $N$-sulfamoyl
$\left(-\mathrm{SO}_{2} \mathrm{NH}-\mathrm{CO}\right)$ groups to transition metals has been rarely investigated especially for the purpose of developing new organometallic sulfamate derivatives and exploring their presumed biological activities. $^{33-35}$

On the other hand, organotin complexes have been found to be encouraging agents for stimulating anticancer activity, many of them are as effective or even better than traditional drugs. ${ }^{36-39}$ In our previous work, we have reported the synthesis of some new $\mathrm{Sn}(\mathrm{IV})$ complexes with 2-alkylaminobenzimidazole ligands. ${ }^{40}$ In the current work, we describe synthesis, characterization and thermal studies of dimethyltin dichloride adduct with $N$-(2-hydroxyphenyl) substituted aryloxy sulfamates. The molecular structure of the opted multi-dentate sulfamate might affect the planarity, hydrophobicity, and coordination geometry of tin complexes and perhaps the anticancer activity of tin-based agents.

\footnotetext{
*For correspondence

Electronic supplementary material: The online version of this article (https://doi.org/10.1007/s12039-018-1586-1) contains supplementary material, which is available to authorized users.
} 


\section{Experimental}

\subsection{Materials and methods}

The melting point of the complexes was recorded by a differential scanning calorimetric instrument (DSC 131 evoSetaram, France). The IR spectra were measured using a Nicolet iS5 Infrared Spectrometer in $\mathrm{KBr}$ disc (Thermo Scientific, USA). ${ }^{1} \mathrm{H}$ NMR, ${ }^{13} \mathrm{C}$ NMR and ${ }^{119}$ Sn spectra were recorded by Bruker Avance 300 spectrometer (Bruker, France) at 300 and $75 \mathrm{MHz}$, respectively. Chemical shifts were reported in ppm from internal TMS for ${ }^{1} \mathrm{H},{ }^{13} \mathrm{C}$ and ${ }^{119} \mathrm{Sn}$. Elemental analysis was obtained by an Exeter Analytical CE-440 Elemental instrument (Exeter Analytical, UK). $\mathrm{X}$-ray spectra were recorded by an Oxford X-calibur Gemini diffractometer (Santa Clara, California, USA) equipped with EOS CCD detector using monochromated Mo Ka radiation $(\mathrm{k}=0.71073 \AA)$ at room temperature. All reagents and solvents used in this study were commercially available (from Sigma-Aldrich) and were used without further purification. The intermediate compounds were prepared according to the literature methods.

\subsection{Synthesis of substituted phenyloxy (2-hydroxyben zoyl)sulfamates $\mathbf{2 a - c}$}

Freshly prepared and distilled aryloxysulfonyl isocyanate (1 equiv.) and salicylic acid (1 equiv.) were taken in a round bottom flask and anhyd. toluene (10 mL) was added to it followed trimethylamine ( 0.05 equiv.). Then it was stirred in an argon atmosphere at room temperature. The reaction was monitored by TLC and was found to be completed after $30 \mathrm{~min}$. The crude solid was filtered and recrystallized from carbon tetrachloride.

2.2.1 Mesityl (2-hydroxybenzoyl)sulfamate (2a): White solid. Yield: $94 \%$. M.p.: $74^{\circ} \mathrm{C}$. IR $\left(\mathrm{cm}^{-1}\right)$ : $\nu_{\mathrm{OH}} 3444, \nu_{\mathrm{NH}}$ $3355, v_{\mathrm{CHarom}} 3076, v_{\mathrm{C}=\mathrm{O}} 1658, v_{\mathrm{C}=\text { Carom }} 1612,1549,1475$, 1448 , $\nu_{\mathrm{SO} 2} 1350 .{ }^{1} \mathrm{H}$ NMR $\left(\delta, \mathrm{ppm}\right.$ in $\left.\mathrm{CDCl}_{3}\right): 7.9-6.6(\mathrm{~m}$; $\left.\mathrm{H}_{\text {arom }}, 6 \mathrm{H}\right), 5.4(\mathrm{br}, \mathrm{NH}, 1 \mathrm{H}), 4.4(\mathrm{~s}, \mathrm{OH} ; 1 \mathrm{H}), 2.4-2.3(2 \mathrm{~s}$, $\left.\mathrm{CH}_{3 \text { arom }} ; 9 \mathrm{H}\right) .{ }^{13} \mathrm{C}$ NMR $\left(\delta\right.$, ppm in $\left.\mathrm{CDCl}_{3}\right): \delta 167.2,160.4$, 143.4, 134.1, 129.2, 127.7, 119.9, 117.5, 115.2, 21.8, 16.5 . Anal. Calculated(\%) for $\mathrm{C}_{16} \mathrm{H}_{17} \mathrm{NO}_{5} \mathrm{~S}: \mathrm{C}, 57.30 ; \mathrm{H}, 5.10 ; \mathrm{N}$, 4.17; Found(\%): C, 57.27; H, 5.09; N, 4.14.

2.2.2 2,4,6-Trichlorophenyl (2-hydroxybenzoyl)sulfa mate (2b): White solid. Yield: $91 \%$. M.p.: $86^{\circ} \mathrm{C}$. IR $\left(\mathrm{cm}^{-1}\right)$ : $\nu_{\mathrm{OH}} 3436, \nu_{\mathrm{NH}} 3361, \nu_{\mathrm{CHarom}} 3087, \nu_{\mathrm{C}=\mathrm{O}} 1682, \nu_{\mathrm{C}=\text { Carom }}$ $1614,1568,1473, v_{\mathrm{SO} 2} 1378 .{ }^{1} \mathrm{H}$ NMR $\left(\delta, \mathrm{ppm}\right.$ in $\left.\mathrm{CDCl}_{3}\right)$ : $7.7-7.0$ (m; $\left.\mathrm{H}_{\text {arom }}, 6 \mathrm{H}\right), 6.2$ (br, NH, 1H), 4.1 (s, OH; 1H). ${ }^{13} \mathrm{C}$ NMR $\left(\delta, \mathrm{ppm}\right.$ in $\left.\mathrm{CDCl}_{3}\right): \delta 168.2,161.4,145.9,134.3$, 130.0, 129.6, 120.1, 117.9, 115.8. Anal. Calculated(\%) for $\mathrm{C}_{13} \mathrm{H}_{8} \mathrm{Cl}_{3} \mathrm{NO}_{5} \mathrm{~S}: \mathrm{C}, 39.36 ; \mathrm{H}, 2.03 ; \mathrm{N}, 3.53$. Found(\%): C, $39.33 ; \mathrm{H}, 2.00 ; \mathrm{N}, 3.52$.

2.2.34-Fluorophenyl(2-hydroxybenzoyl)sulfamate (2c): White solid. Yield: $93 \%$. M.p.: $69^{\circ} \mathrm{C}$. IR $\left(\mathrm{cm}^{-1}\right): \nu_{\mathrm{OH}} 3448$,
$\nu_{\mathrm{NH}} 3370, v_{\mathrm{CHarom}} 3080, v_{\mathrm{C}=O} 1690,1612,1502, v_{\mathrm{C}=\text { Carom }}$ $1448, \nu_{\mathrm{SO} 2} 1373 .{ }^{1} \mathrm{H}$ NMR $\left(\delta, \operatorname{ppm}\right.$ in $\left.\mathrm{CDCl}_{3}\right): 7.8-6.8(\mathrm{~m}$; $\left.\mathrm{H}_{\text {arom }}, 8 \mathrm{H}\right), 6.5$ (br, NH, 1H), 3.9 (s, OH; $\left.1 \mathrm{H}\right) .{ }^{13} \mathrm{C} \mathrm{NMR}(\delta$, ppm in $\left.\mathrm{CDCl}_{3}\right): \delta 168.5,164.1,161.1,145.2,134.1,129.5$, $121.0,119.9,118.0,117.6,115.4$. Anal. Calculated(\%) for $\mathrm{C}_{13} \mathrm{H}_{10} \mathrm{FNO}_{5} \mathrm{~S}$ : C, 50.15; H, 3.23; N, 4.49. Found(\%): C, $50.14 ; \mathrm{H}, 3.20 ; \mathrm{N}, 4.47$.

\subsection{Synthesis of organotin complexes $\mathbf{3 a} \boldsymbol{a}$}

The alcoholic solution of $1 \mathrm{mmol}$ of dimethyltin dichloride was added with constant stirring to an alcoholic solution of $1 \mathrm{mmol}$ of Sodium salt of substituted aryloxysulfamate ligand. The brown precipitates were instantly obtained. The precipitates were filtered and washed with water and then with Methanol and dried over calcium chloride in a desiccator.

2.3.1 $\left[\mathrm{Me}_{2} \operatorname{Sn}\left(L_{1}\right) \mathrm{Cl}\right](3 \boldsymbol{a})$ : Brown solid. Yield: $54 \%$. M.p.: $373^{\circ} \mathrm{C}$. IR $\left(\mathrm{cm}^{-1}\right)$ : $\nu_{\mathrm{OH}} 3440 ; \nu_{\mathrm{C}=\mathrm{N}} 1608$ and 1522; $\nu_{\mathrm{Sn}-\mathrm{C}}$ 578; $\nu_{\mathrm{Sn}-\mathrm{N}}$ 507. ${ }^{13} \mathrm{C}$ CPMAS NMR (ppm): $183-164(\mathrm{C}=\mathrm{O}$ and $=\mathrm{N}) ; 137-117\left(\mathrm{C}_{\text {arom }}\right) ; 80-40\left(\mathrm{CH}_{3 \text { arom }}\right), 14-8\left(\mathrm{CH}_{3}\right.$ -Sn). Anal. Calculated(\%) for $\mathrm{C}_{18} \mathrm{H}_{22} \mathrm{ClNO}_{5} \mathrm{SSn}: \mathrm{C}, 41.69$; H, 4.28; N, 2.70. Found(\%): C, 41.67; H, 4.25; N, 2.69 .

2.3.2 $\left[\mathrm{Me}_{2} \operatorname{Sn}\left(L_{2}\right) \mathrm{Cl}\right](3 \boldsymbol{b})$ : Brown solid. Yield: in $41 \%$. M.p.: $338^{\circ} \mathrm{C}$. IR data $\left(\mathrm{cm}^{-1}\right): \nu_{\mathrm{OH}} 3452 ; \nu_{\mathrm{C}=\mathrm{N}} 1610$ and $1526 ; \nu_{\mathrm{Sn}-\mathrm{C}} 571 ; \nu_{\mathrm{Sn}-\mathrm{N}} 510 .{ }^{13} \mathrm{C}$ CPMAS NMR (ppm): $182-164(\mathrm{C}=\mathrm{O}$ and $\mathrm{C}=\mathrm{N}) ; 138-116\left(\mathrm{C}_{\text {arom }}\right) ; 14-8\left(\mathrm{CH}_{3}\right.$ -Sn). Anal. Calculated(\%) for $\mathrm{C}_{15} \mathrm{H}_{13} \mathrm{Cl}_{4} \mathrm{NO}_{5} \mathrm{SSn}$ : C, 31.07; H, 2.26; N, 2.42. Found(\%): C, 31.05; H, 2.25; N, 2.41.

2.3.3 $\left[\mathrm{Me}_{2} \mathrm{Sn}\left(\mathrm{L}_{3}\right) \mathrm{Cl}\right](3 \mathrm{c})$ : Brown solid. Yield: 44\%, M.p.: $299^{\circ} \mathrm{C}$. IR data $\left(\mathrm{cm}^{-1}\right): \nu_{\mathrm{OH}} 3444 ; \nu_{\mathrm{C}=\mathrm{N}} 1606$ and 1526; $\nu_{\mathrm{Sn}-\mathrm{C}} 576 ; \nu_{\mathrm{Sn}-\mathrm{N}} 511 .{ }^{13} \mathrm{C}$ CPMAS NMR (ppm): 185-165 $(\mathrm{C}=\mathrm{O}$ and $\mathrm{C}=\mathrm{N}) ; 144-121\left(\mathrm{C}_{\text {arom }}\right) ; 13-8\left(\mathrm{CH}_{3}-\mathrm{Sn}\right)$. Anal. Calculated (\%) for $\mathrm{C}_{15} \mathrm{H}_{15} \mathrm{ClFNO}_{5} \mathrm{SSn}: \mathrm{C}, 36.43 ; \mathrm{H}, 3.06$; N, 2.83. Found(\%): C, 36.40; H, 3.05; N, 2.80.

\section{Results and Discussion}

\subsection{Chemistry}

The synthesis of new sulfamate derivative ligands $\left(\mathrm{L}_{\mathrm{n}} \mathrm{H}\right)$ $\mathbf{2 a}-\mathbf{c}$ has been carried out in a basic medium at room temperature by the addition of 2-hydroxy benzoic acid to a series of substituted aryloxy sulfonylisocyanates 1a-c which followed by decarboxylation reaction ${ }^{41}$ (Scheme 1). The latter isocyanates were prepared according to literature methods. ${ }^{42,43}$

Dimethylthin phenyloxy (2-hydroxybenzoyl)sulfa mate complexes 3a-c $\left[\mathrm{Me}_{2} \mathrm{Sn}\left(\mathrm{L}_{\mathrm{n}}\right) \mathrm{Cl}\right]$ were synthesized from $N$-(2-hydroxyphenoyl) substituted aryloxy sulfamates $\mathbf{2 a}-\mathbf{c}$ in alkaline medium, and its metal complexes were prepared. As a result of the electroattractor effect of both sulfonyl and carbonyl groups, 


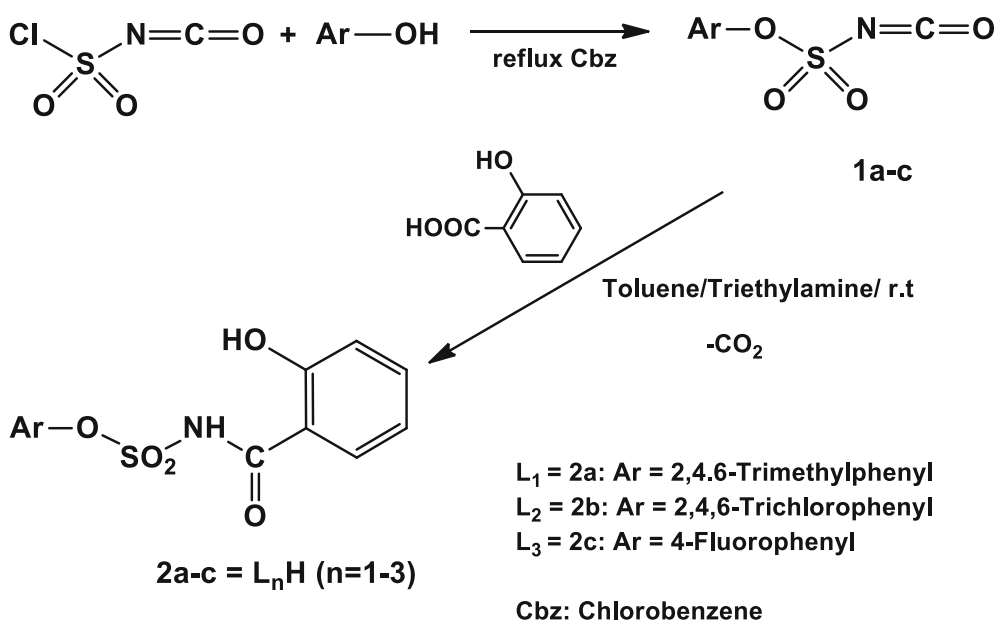

Scheme 1. Synthesis of substituted phenyloxy (2-hydroxybenzoyl)sulfamates 2a-c.

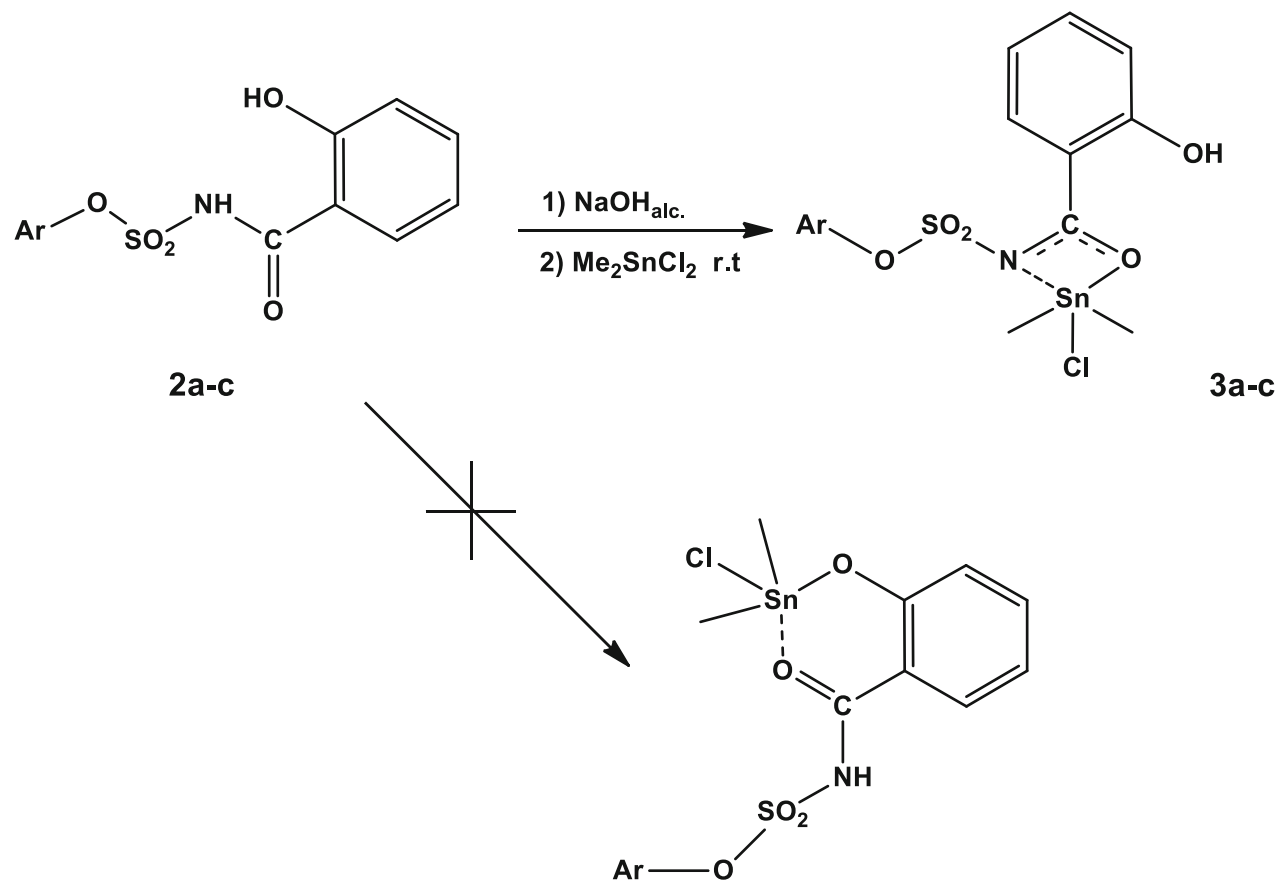

Scheme 2. Synthesis of sulfamate complexes $\mathbf{3 a - c .}$

the proton sulfamate group $\mathrm{NH}$ is more acidic than the proton hydroxyl group $\mathrm{OH}$; therefore, a significant conjugated bidentate ligand would be formed and reacted with the Tin halide, in 1:1 molar ratio, as shown in Scheme 2.

The composition of isolated complexes was confirmed by the findings obtained from elemental analyses which performed by an Exeter Analytical CE-440 Elemental instrument. It has been found that in all ligands $\left(\mathrm{L}_{\mathrm{n}} \mathrm{H}\right) \mathbf{2 a}-\mathbf{c}$, one chloride was substituted by monoanionic ligands and furnished with moderate yields their corresponding mononuclear complexes $\mathbf{3 a - c}$.

Upon coordination to tin atom, many absorption bands were markedly shifted. The three complexes 3a-c exhibited broad bands at 3440,3449 , and $3444 \mathrm{~cm}^{-1}$ respectively, due to the hydroxyl $(\mathrm{OH})$ chromophore. Thus, the absorption bands observed at $3375 \mathrm{~cm}^{-1}$ and $1656 \mathrm{~cm}^{-1}$ in IR spectrum of $2 \mathrm{c}$ which assigned to $(\mathrm{N}$ $\mathrm{H})$ and $(\mathrm{C}=\mathrm{O})$ groups respectively, were disappeared in the homologous IR spectrum of $\mathbf{3 c}$ in favor of appearance of new bands exhibited at $(1609,1514) \mathrm{cm}^{-1}$ and $(565-547) \mathrm{cm}^{-1}$ which might be attributed to $(\mathrm{C}=\mathrm{N})$ and (Sn-C) chromophores correspondently (Figure 1). The absorption bands of both carbonyl and imino groups are hardly observed probably because of the high conjugation (Scheme 2).

The ${ }^{13} \mathrm{C}$ NMR spectra of compounds 3a-c displayed one set of resonances which were consistent with the presence of one organotin(IV) moiety and equivalence of the methyl groups attached to tin on the NMR time 
scale (Figure 2). Indeed, the signals observed at 14$8 \mathrm{ppm}$ were assigned to $\mathrm{CH}_{3}-\mathrm{Sn}$ carbon group, whereas, the signals exhibited at $80-40 \mathrm{ppm}$ were attributed to the aromatic methyl $\left(\mathrm{CH}_{3 \text { arom }}\right)$ carbon group. The aromatic carbons displayed signals at $137-117 \mathrm{ppm}$. The $\mathrm{C}=\mathrm{O}$ and $\mathrm{C}=\mathrm{N}$ carbon groups presented signals located at 185-165 ppm.

$\mathrm{X}$-ray spectra of synthesized complexes $\mathbf{3 a}-\mathbf{c}$ were recorded by an Oxford X-calibur Gemini diffractometer

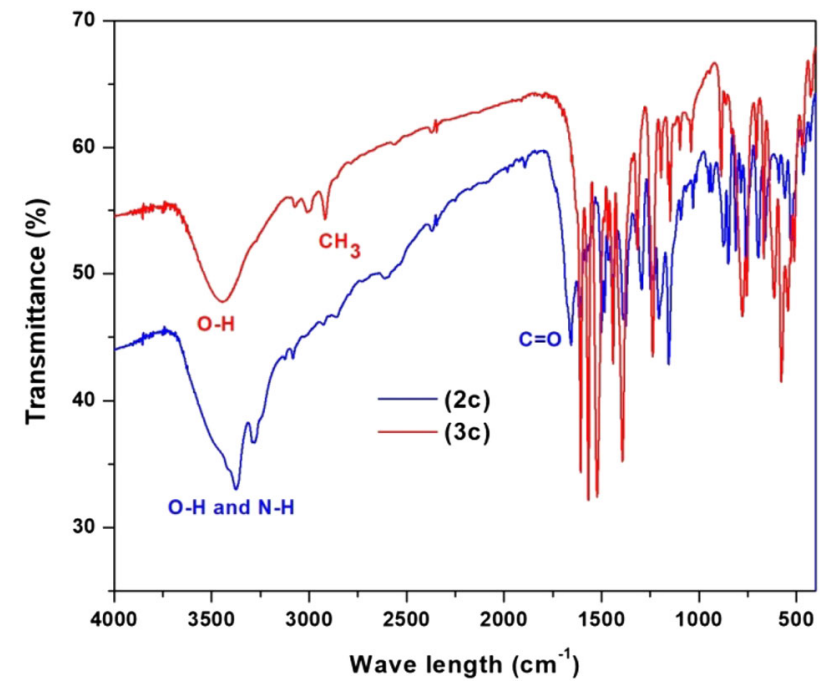

Figure 1. Infrared spectra of ligand $\mathbf{2 c}$ and its corresponding complex $\mathbf{3 c}$. and shown in Figure 3. All spectra revealed sharp peaks with significant diffraction intensity and low background. Indexing of the powder diffraction pattern and searching space group of the crystal specimen were determined using $\mathrm{X}$-pert high score plus software program after peak searching (Figure 3). Particular structural properties and features obtained are presented in Tables $1-3$, respectively. The organotin compounds 3a and $\mathbf{3 b}$ show tetragonal crystal system, while, the crystal structure of complex $\mathbf{3 c}$ belong to the hexagonal system. Crystallite size $D p$ for all complexes $\mathbf{3 a}-\mathbf{c}$ have been calculated using Scherrer formula ${ }^{44}$ and obtained values are $142 \mathrm{~nm}, 76 \mathrm{~nm}$, and $70 \mathrm{~nm}$, respectively.

$D_{p}=\frac{K \lambda}{\beta \cos \theta}$

$D_{p}$ is the size of particles of crystals in the form of powder, $K$ is a dimensionless shape factor with a value close to unity, $\lambda$ is the $\mathrm{X}$-ray wavelength, $\beta$ is the line broadening at half the maximum intensity (FWHM), after subtracting the instrumental line broadening, in radians and $\theta$ is the Bragg angle.

Tables 1-3 show that all the diffraction peaks in the pattern of the synthesized organotin complexes $\mathbf{3 a}-\mathbf{c}$ can be readily indexed by a set of lattice parameters. The relative deviations between the calculated and experimental are about $1.13 \%, 0.37 \%$, and $0.36 \%$ for products

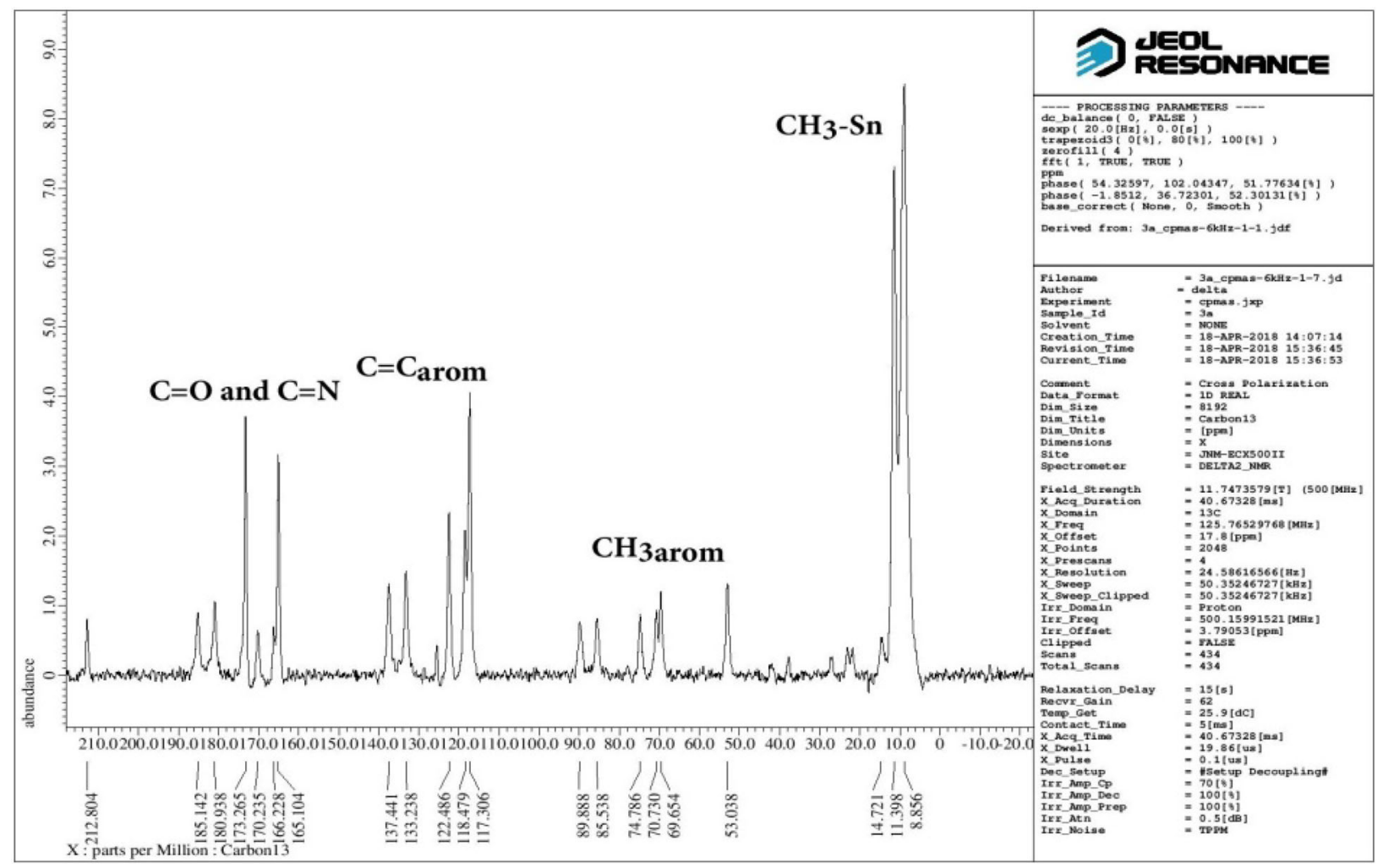

Figure 2. ${ }^{13} \mathrm{C}$ CPMAS NMR spectrum of organotin complex 3a. 

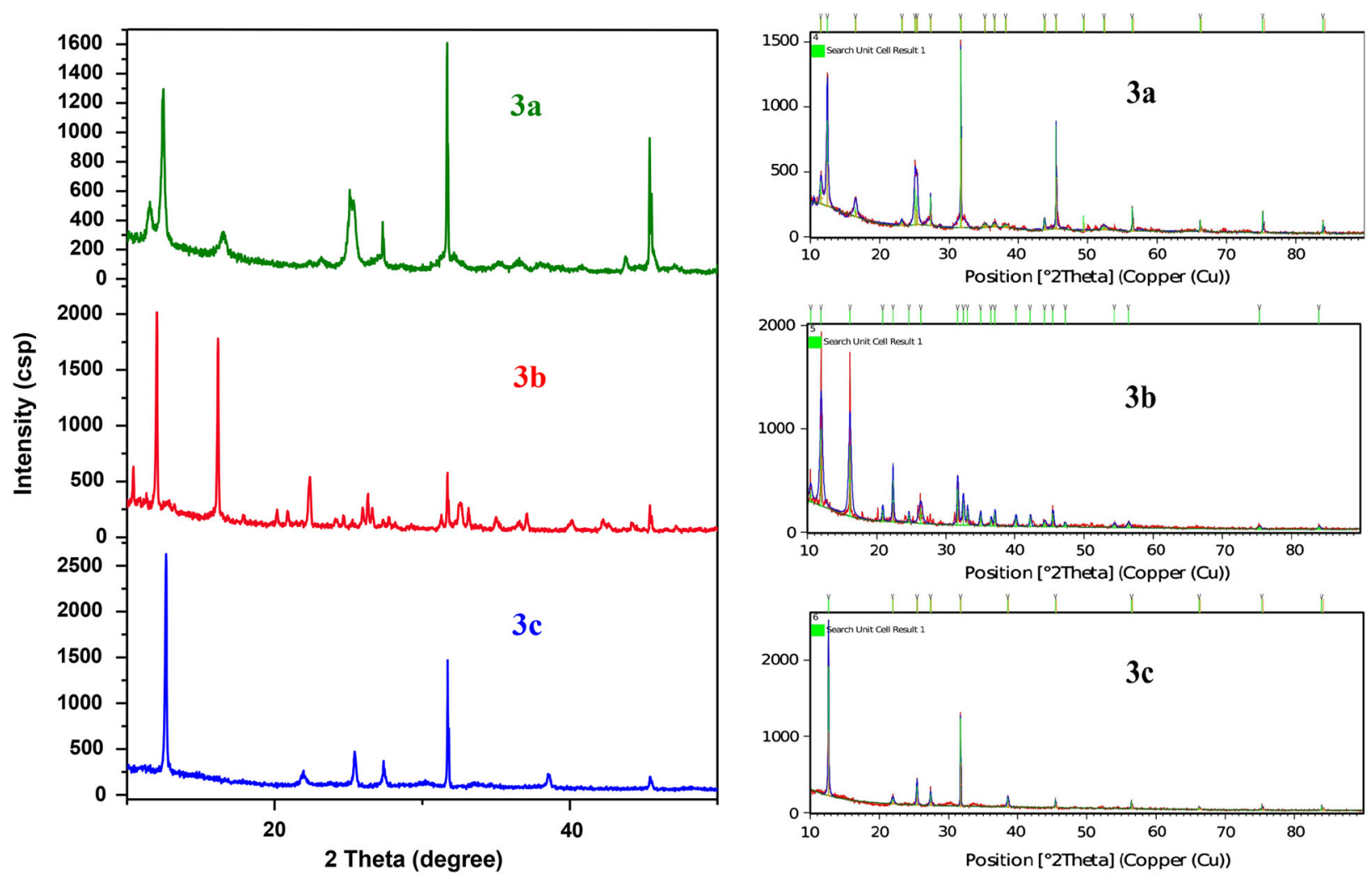

Figure 3. X-ray patterns of complexes $\mathbf{3 a - c}$ and indexation peak using X-pert high score plus software.

Table 1. Experimental data and calculated results for the powder X-ray diffraction pattern of 3a, tetragonal symmetry.

\begin{tabular}{lcccccr}
\hline Peak no. & $\mathbf{2 \theta}(\mathbf{c})\left[^{\circ}\right]$ & $\mathbf{2 \theta}(\mathbf{o})\left[\left[^{\circ}\right]\right.$ & $\mathbf{d}-\mathbf{s p} .(\mathbf{c})[\AA]$ & d-sp. $(\mathbf{o})[\AA]$ & Relative intensity $(\boldsymbol{\%})$ & $\boldsymbol{h k l}$ \\
\hline 1 & 11.5707 & 11.4789 & 7.641693 & 7.702639 & 12.56 & 100 \\
2 & 12.4071 & 12.3876 & 7.128348 & 7.139563 & 47.90 & 101 \\
3 & 16.3915 & 16.4768 & 5.403492 & 5.375722 & 5.26 & 110 \\
4 & 23.2616 & 23.131 & 3.820846 & 3.842123 & 2.31 & 200 \\
5 & 24.9628 & 25.0595 & 3.564174 & 3.550645 & 19.92 & 202 \\
6 & 25.3287 & 25.3407 & 3.513511 & 3.511875 & 15.76 & 105 \\
7 & 27.593 & 27.2856 & 3.23011 & 3.2658 & 16.02 & 212 \\
8 & 31.6343 & 31.6316 & 2.826082 & 2.826311 & 100.00 & 007 \\
9 & 35.2044 & 35.134 & 2.547231 & 2.552172 & 2.24 & 300 \\
10 & 36.3925 & 36.4842 & 2.466749 & 2.460762 & 2.27 & 302 \\
11 & 38.2233 & 38.0732 & 2.352707 & 2.361631 & 1.46 & 108 \\
12 & 43.6406 & 43.7133 & 2.072384 & 2.069108 & 6.21 & 322 \\
13 & 45.2256 & 45.3761 & 2.003371 & 1.997076 & 58.11 & 218 \\
14 & 49.3459 & 49.3517 & 1.845302 & 1.845099 & 8.75 & 411 \\
15 & 52.2106 & 52.2846 & 1.75059 & 1.748288 & 1.93 & 1011 \\
16 & 56.5098 & 56.3931 & 1.627179 & 1.63027 & 13.26 & 2011 \\
17 & 66.0679 & 66.1456 & 1.413041 & 1.411568 & 5.67 & 0014 \\
18 & 75.1509 & 75.2085 & 1.263187 & 1.262364 & 11.88 & 602 \\
19 & 83.9897 & 83.9029 & 1.151308 & 1.152279 & 6.41 & 5111 \\
\hline
\end{tabular}

Lattice parameters calculated: $\mathrm{a}=7.64 \AA, \mathrm{b}=7.64 \AA, \mathrm{c}=19.78 \AA$ and $\alpha=\beta=\gamma=90^{\circ}$

Particle size of complex 3a: $142 \mathrm{~nm}, \mathrm{~V}=1155.21 \AA^{3}$. (2Theta Zero Shift $\left[{ }^{\circ}\right], 0.0(1)$ ). 
Table 2. Experimental data and calculated results for the powder X-ray diffraction pattern of $\mathbf{3 b}$, tetragonal symmetry.

\begin{tabular}{lcccccc}
\hline Peak no. & $\mathbf{2 \theta}(\mathbf{c})\left[{ }^{\circ}\right]$ & $\mathbf{2 \theta}(\mathbf{o})\left[^{\circ}\right]$ & $\mathbf{d}-\mathbf{s p .}(\mathbf{c})[\AA]$ & $\mathbf{d}$-sp. $(\mathbf{o})[\AA]$ & Relative intensity $(\boldsymbol{\%})$ & $\boldsymbol{h} \boldsymbol{k} \boldsymbol{~}$ \\
\hline 1 & 10.4175 & 10.4552 & 8.484892 & 8.454357 & 14.84 & 002 \\
2 & 11.9636 & 11.9934 & 7.391633 & 7.373334 & 100.00 & 101 \\
3 & 16.1204 & 16.1441 & 5.493742 & 5.485749 & 91.50 & 111 \\
4 & 20.9224 & 20.8978 & 4.242446 & 4.247382 & 14.54 & 004 \\
5 & 22.259 & 22.3631 & 3.990629 & 3.972279 & 53.07 & 201 \\
6 & 24.7858 & 24.6695 & 3.589231 & 3.605881 & 10.22 & 211 \\
7 & 26.4248 & 26.3521 & 3.370199 & 3.379341 & 19.68 & 212 \\
8 & 31.6088 & 31.7311 & 2.828297 & 2.817677 & 45.82 & 006 \\
9 & 32.5715 & 32.5138 & 2.746871 & 2.751613 & 28.86 & 222 \\
10 & 33.1246 & 33.1522 & 2.702254 & 2.700069 & 18.31 & 301 \\
11 & 34.9268 & 35.0121 & 2.566839 & 2.560783 & 13.10 & 311 \\
12 & 36.4364 & 36.5498 & 2.463877 & 2.456496 & 8.53 & 303 \\
13 & 37.0534 & 37.0893 & 2.424255 & 2.421989 & 15.59 & 007 \\
14 & 40.2131 & 40.1444 & 2.240761 & 2.244435 & 10.89 & 216 \\
15 & 42.3893 & 42.2347 & 2.13062 & 2.138059 & 12.02 & 305 \\
16 & 44.4152 & 44.3299 & 2.038026 & 2.041746 & 5.49 & 401 \\
17 & 45.4878 & 45.482 & 1.99243 & 1.99267 & 16.86 & 118 \\
18 & 47.2275 & 47.2446 & 1.923011 & 1.922356 & 4.77 & 331 \\
19 & 54.4033 & 54.3872 & 1.685099 & 1.685562 & 4.36 & 424 \\
20 & 56.4471 & 56.4298 & 1.62884 & 1.629297 & 5.48 & 1110 \\
21 & 75.3292 & 75.3317 & 1.26064 & 1.260604 & 2.95 & 536 \\
22 & 83.9728 & 83.9769 & 1.151497 & 1.151451 & 3.45 & 635 \\
\hline
\end{tabular}

Lattice parameters calculated: $\mathrm{a}=8.212 \AA, \mathrm{b}=8.212 \AA, \mathrm{c}=16.97 \AA$ and $\alpha=\beta=\gamma=90^{\circ}$, Particle size of complex 3b: $76 \mathrm{~nm}, \mathrm{~V}=1144.26 \AA^{3}$. (2Theta Zero Shift $\left[{ }^{\circ}\right],-0.01(6)$ ).

Table 3. Experimental data and calculated results for the powder X-ray diffraction pattern of 3c, hexagonal symmetry.

\begin{tabular}{lcccccc}
\hline Peak no. & $\mathbf{2} \boldsymbol{\theta}(\mathbf{c})\left[^{\circ}\right]$ & $\mathbf{2} \boldsymbol{\theta}(\mathbf{o})\left[^{\circ}\right]$ & d-sp. $(\mathbf{c})[\AA]$ & d-sp. $(\mathbf{o})[\AA]$ & Relative intensity $(\boldsymbol{\%})$ & $\boldsymbol{h k l}$ \\
\hline 1 & 12.6202 & 12.6337 & 7.008465 & 7.00105 & 100.00 & 200 \\
2 & 21.9487 & 21.9512 & 4.046339 & 4.045873 & 7.20 & 220 \\
3 & 25.3969 & 25.4268 & 3.504233 & 3.500174 & 21.24 & 400 \\
4 & 27.4867 & 27.392 & 3.242368 & 3.253358 & 12.40 & 211 \\
5 & 31.6927 & 31.7292 & 2.820999 & 2.817842 & 71.49 & 311 \\
6 & 38.5047 & 38.5464 & 2.336155 & 2.333723 & 8.12 & 600 \\
7 & 45.6151 & 45.4493 & 1.987164 & 1.994027 & 7.57 & 112 \\
8 & 12.6202 & 12.6337 & 7.008465 & 7.00105 & 4.02 & 200 \\
9 & 21.9487 & 21.9512 & 4.046339 & 4.045873 & 1.36 & 220 \\
10 & 25.3969 & 25.4268 & 3.504233 & 3.500174 & 2.19 & 400 \\
11 & 27.4867 & 27.392 & 3.242368 & 3.253358 & 1.49 & 211 \\
\hline
\end{tabular}

Lattice parameters calculated: $\mathrm{a}=16.19 \AA, \mathrm{b}=16.19 \AA \mathrm{n}, \mathrm{c}=4.10 \AA$ and $\alpha=\beta=90^{\circ}, \gamma=120^{\circ}$ Particle size of complex 3c: $70 \mathrm{~nm}, \mathrm{~V}=930.13 \AA^{3}$. (2 Theta Zero Shift $\left[^{\circ}\right],-0.0(1)$ ).

$\mathbf{3 a}, \mathbf{3 b}$ and $\mathbf{3 c}$ correspondently, which could suggest that all complexes are single-phase compounds.

\subsection{DSC studies for the complexes $\mathbf{3 a - c}$}

The thermal curves exhibited slight endothermic peaks nearly at $373{ }^{\circ} \mathrm{C}, 338^{\circ} \mathrm{C}$, and $299^{\circ} \mathrm{C}$ for the complexes $\mathbf{3 a}, \mathbf{3 b}$, and 3c, respectively, which followed by heat flow gradually rise until $649{ }^{\circ} \mathrm{C}, 652{ }^{\circ} \mathrm{C}$, and $646{ }^{\circ} \mathrm{C}$ correspondently (Figure 4). Indeed, the combustion process of complex 3a was achieved in two different stages. The related DSC curve revealed intense exothermic peak at $664{ }^{\circ} \mathrm{C}$ in the temperature range $649-664{ }^{\circ} \mathrm{C}$ followed by two successive endothermic peaks at 666 and $669{ }^{\circ} \mathrm{C}$, respectively with an extrapolated combustion enthalpy equal to $-699.12 \mathrm{~J}_{\mathrm{g}} \mathrm{g}^{-1}$. However, the decomposition mechanism of $\mathbf{3 b}$ was carried out in two similar stages. The corresponding DSC curve exhibited 


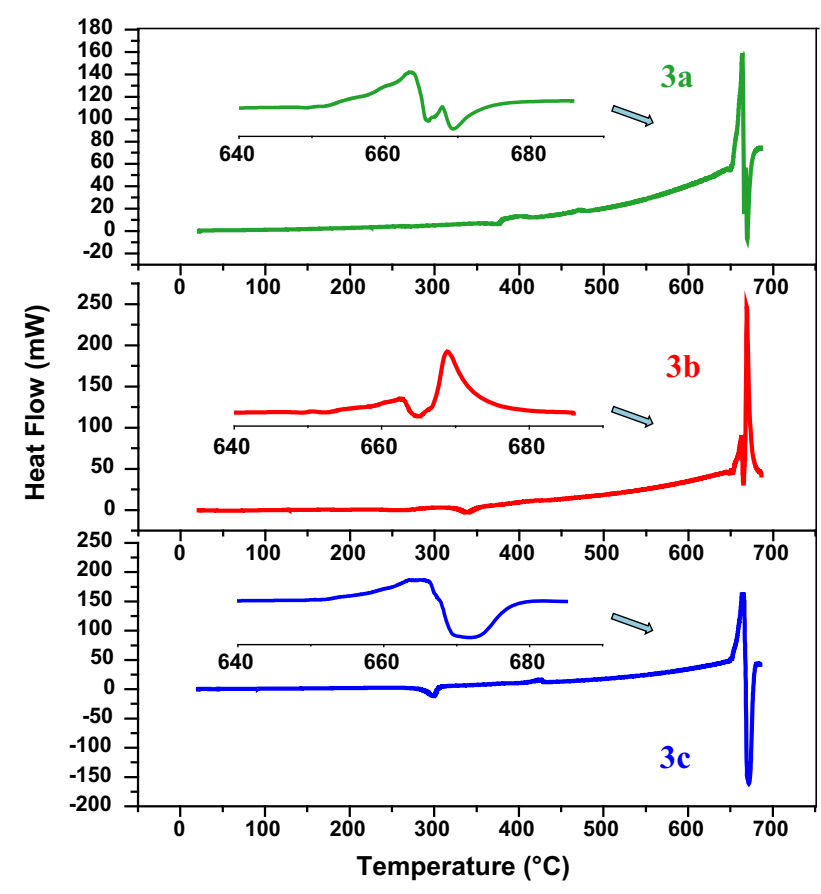

Figure 4. DSC thermograms of complexes 3a-c.

sharp exothermic peak which presents two maxima at $662^{\circ} \mathrm{C}$ and $668^{\circ} \mathrm{C}$, respectively in the temperature range $652-684{ }^{\circ} \mathrm{C}$ with total determined enthalpy combustion

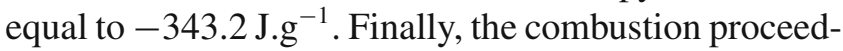
ing of $\mathbf{3} \mathbf{c}$ was accomplished in two different stages. The associated DSC curve displayed an intense exothermic peak at $665^{\circ} \mathrm{C}$ in the temperature range $646-667^{\circ} \mathrm{C}$ pursued by an endothermic peak at $671{ }^{\circ} \mathrm{C}$ with calculated enthalpy combustion equal to $-755.5 \mathrm{~J} \mathrm{~g}^{-1}$. It is important to notice that all derivatives 3a-c present higher thermal stability and hardly decompose at low temperature; this may be due to the absence of small molecules which could be attached to the complexes (Figure 4).

\section{Conclusions}

Three monomeric pentacoordinate organotin(IV) complexes were successfully synthesized and characterized using various analytical approaches. The results of spectroscopic analyses were in agreement with the suggested structures of the compounds. All the complexes 3a-c were obtained via $O, N$ coordination to tin center by their homologous ligands $\mathbf{2 a}-\mathbf{c}$, respectively. The analysis of XRD spectra revealed that products $\mathbf{3 a}$ and $3 \mathbf{b}$ crystalize in the tetragonal system, while, the crystal structure of complex $\mathbf{3 c}$ refers to the hexagonal system. DSC studies showed that all the organotin compounds 3a-c possess higher thermal stability, a similar range of decomposition temperature, and slightly comparable combustion processes.

\section{Supplementary Information (SI)}

Supplementary Information for this article is available at www.ias.ac.in/chemsci.

\section{Acknowledgements}

The authors wish to acknowledge the approval and the support of this research study by the grant $\mathrm{N}^{\circ}$. SCI-2017-1-7-F-6928 from the Deanship of Scientific Research in Northern Border University, Arar, KSA.

\section{References}

1. Kaise A, Ohta K, Shirata C and Endo Y 2017 Design and synthesis of p-carborane-containing sulfamates as multitarget anti-breast cancer agents Bioorg. Med. Chem. 256417

2. Caira M R, Bourne S A and Samsodien H 2015 Thermal, X-ray Structural, and Dissolution Characteristics of Solid Forms Derived from the Anticancer Agents 2-Methoxyestradiol and 2-Methoxyestradiol-3,17-O, OBis-Sulfamate J. Pharm. Sci. 103418

3. Kumar B S, Raghuvanshi D S, Hasanain M, Alam S, Sarkar J, Mitra K, Khan F and Negi A S 2016 Recent Advances in chemistry and pharmacology of 2-methoxyestradiol: An anticancer investigational drug Steroids $\mathbf{1 1 0} 9$

4. Rami M, Dubois L, Parvathaneni N-K, Alterio V, van Kuijk S J A, Monti S M, Lambin P, De Simone G, Supuran C T and Winum J -Y 2013 Hypoxia-Targeting Carbonic Anhydrase IX Inhibitors by a New Series of Nitroimidazole-Sulfonamides/Sulfamides/Sulfamates $J$. Med. Chem. 568512

5. Shah R, Singh J, Singh D, Jaggi A S and Singh N 2016 Sulfatase inhibitors for recidivist breast cancer treatment: A chemical review Euro. J. Med. Chem. 114170

6. Gadakh B, Vondenhoff G, Lescrinier E, Rozenski J, Froeyen M and Van Aerschot A 2014 Base substituted 5'-O-(N-isoleucyl)sulfamoyl nucleoside analogues as potential antibacterial agents Bioorg. Med. Chem. 22 2875

7. Cherian P T, Yao J, Leonardi R, Maddox M M, Luna V A, Rock C O and Lee R E 2012 Acyl-sulfamates target the essential glycerol-phosphate acyltransferase (PlsY) in Gram-positive bacteria Bioorg. Med. Chem. 204985

8. Xu L -C and Siedlecki C A 2016 Antibacterial polyurethanes Stuart L Cooper and Jianjun Guan (Eds.) Advances in Polyurethane Biomaterials (Witney, Oxford, UK: Woodhead Publishing) p. 247

9. Gmurek M, Horn H and Majewsky M 2015 Phototransformation of sulfamethoxazole under simulated sunlight: Transformation products and their antibacterial activity toward Vibrio fischeri Sci. Total Environ. 53858

10. Capasso C and Supuran C T 2015 Bacterial Carbonic Anhydrases as Drug Targets C T Supuran and G De Simone (Eds.) Carbonic Anhydrases as Biocatalysts First edn. (Amsterdam, Netherlands: Elsevier) p. 275 
11. Römer W, Oettel M and Schwarz S 1998 Scavestrogen sulfamates: correlation between estrone sulfatase inhibiting and antioxidant effects Can. J. Physiol. Pharmacol. 7699

12. Marciniak G and Petty M G 1996 Design and biological evaluation of new antioxidants for use in cerebrovascular disorders Drug. Future 211037

13. Winum J - Y, Scozzafava A, Montero J -L and Supuran C T 2005 Sulfamates and their therapeutic potential Med. Res. Rev. 25186

14. Musa M A, Cooperwood J S and Khan M O F 2008 A Review of Coumarin Derivatives in Pharmacotherapy of Breast Cancer Curr. Med. Chem. 152664

15. Jin H, Wright M, Pastor R, Mish M, Metobo S, Jabri S, Lansdown R, Cai R, Pyun P, Tsiang M, Chen X and Kim C U 2008 Tricyclic HIV integrase inhibitors: Potent and orally bioavailable C5-aza analogs Bioorg. Med. Chem. Lett. 181388

16. Flynn S and Babi M A 2017 Anticonvulsants F J Dowd, B Johnson and A Mariotti (Eds.) Pharmacology and Therapeutics for Dentistry Seventh edn. (Amsterdam, Netherlands: Elsevier) p. 176

17. Villalba M L, Enrique A V, Higgs J, Castaño R A, Goicoechea S, Taborda F D, Gavernet L, Lick I D, Marder M and Bruno-Blanch L E 2016 Novel sulfamides and sulfamates derived from amino esters: Synthetic studies and anticonvulsant activity Eur. J. Pharmacol. $\mathbf{7 7 4} 55$

18. Kubicki M and Codding P W 2001 The anticonvulsant sulfamates. 2. (1,4-benzodioxin-2(3H)-yl)- and (1,2,3,4tetrahydro-2-naphthalenyl) methyl sulfamic acid esters J. Mol. Struct. 56165

19. Gavernet L, Barrios I A, Sella Cravero M and BrunoBlanch L E 2007 Design, synthesis, and anticonvulsant activity of some sulfamides Bioorg. Med. Chem. 15 5604

20. Su Y -f, Wang G -Bo, Kuo D T F, Chang M -1 and Shih Y -h 2016 Photoelectrocatalytic degradation of the antibiotic sulfamethoxazole using $\mathrm{TiO}_{2} / \mathrm{Ti}$ photoanode Appl. Catal. B: Environ. 186184

21. Connor E E 1998 Sulfonamide antibiotics Prim. Care Update Ob Gyns. 532

22. Scozzafava A, Supuran C T and Carta F 2013 Antiobesity carbonic anhydrase inhibitors: a literature and patent review Expert Opin. Ther. Pat. 23725

23. Supuran C T 2016 How many carbonic anhydrase inhibition mechanisms exist? J. Enzym. Inhib. Med. Chem. 31345

24. Carta F and Supuran C T 2013 Diuretics with carbonic anhydrase inhibitory action: a patent and literature review (2005-2013) Expert Opin. Ther. Pat. 23 681

25. Boyd III A E 1998 Sulfonylurea Receptors, Ion Channels, and Fruit Flies Diabetes 37847

26. Maren T H 1976 Relations Between Structure and Biological Activity of Sulfonamides Annu. Rev. Pharmacol. Toxicol. 16309

27. Carta F, Di Cesare Mannelli L, Pinard M, Ghelardini C, Scozzafava A, McKenna R and Supuran C T 2015 A class of sulfonamide carbonic anhydrase inhibitors with neuropathic pain modulating effects Bioorg. Med. Chem. 231828
28. Weber A, Casini A, Heine A, Kuhn D, Supuran C T, Scozzafava A and Klebe G 2004 Unexpected nanomolar inhibition of carbonic anhydrase by COX-2 selective celecoxib: New pharmacological opportunities due to related binding site recognition J. Med. Chem. 47550

29. Supuran C T, Scozzafava A and Casini A 2003 Carbonic anhydrase inhibitors Med. Res. Rev. 23146

30. Supuran C T and Scozzafava A 2002 Applications of carbonic anhydrase inhibitors and activators in therapy Exp. Opin. Ther. Patents 12217

31. Supuran C T and Scozzafava A 2000 Carbonic anhydrase inhibitors and their therapeutic potential Exp. Opin. Ther. Patents 10575

32. Scozzafava A, Owa T, Mastrolorenzo A and Supuran C T 2003 Anticancer and antiviral sulfonamides Curr. Med. Chem. 10925

33. Slyvka Yu I, Fedorchuk A A, Pokhodylo N T, Lis T, Kityk I V and Mys'kiv M G 2018 A novel copper(I) sulfamate $\pi$-complex based on the 5-(allylthio)-1(3,5-dimethylphenyl)-1H-tetrazole ligand: Alternatingcurrent electrochemical crystallization, DFT calculations, structural and NLO properties studies Polyhedron 14786

34. Kessissoglou D P, Manoussakis G E, Hatzidimitriou A G and Kanatzidis M G 1987 Synthesis and characterization of sulfonylurea complexes with cadmium(2+), mercury $(2+)$ and silver(+). Crystal and molecular structures of potassium tris(chlorpropamide)cadmate and bis(tolbutamide)mercury Inorg. Chem. 261395

35. Cleveland J M 1968 Sulfamate complexes of plutonium(IV) Inorg. Chem. 7874

36. Carcelli M, Pelizzi C, Pelizzi G, Mazza P and Zani F 1995 The different behaviour of the di-2-pyridylketone 2thenoylhydrazone in two organotin compounds. Synthesis, X ray structure and biological activity J. Organomet. Chem. 48855

37. Gielen M2002 Organotin compounds and their therapeutic potential: a report from the Organometallic Chemistry Department of the Free University of Brussels App. Organomet. Chem. 16481

38. Gielen M 1996 Tin-based antitumour drugs Coord. Chem. Rev. 15141

39. Nath M, Pokharia S and Yadav R 2001 Organotin(IV) complexes of amino acids and peptides Coord. Chem. Rev. 21599

40. Akremi A, Noubigh A and Abualreish M J A 2018 Novel Organotin(IV) Complexes Derived from Chiral Benzimidazoles: Synthesis, Molecular Structure and Spectral Properties Orient. J. Chem. 34764

41. Sbihi H, Beji M and Baklouti A 2008 Reaction of Acids and Diacids with Aroxy(alcoxy)sulfonyl Isocyanates: Synthesis of N-Acylsulfamates, Disulfamates, and N,N'Disulfonylureas Synth. Comm. 382490

42. Lohaus G 1972 Darstellung und umsetzungen von aryloxysulfonylisocyanaten Chem. Ber. 1052791

43. Hedayatullah M and Brault J F 1977 Polyhalogenated aryl-N-chlorosulfonylcarbamates and aminosulfates $C$. R. Acad. Sci. C 285153

44. Harris R K, Sebald A, Furlani D and Tagliavini G 1988 High-resolution solid-state tin-119 NMR investigations of organotin halides $\mathrm{R}_{3} \mathrm{SnX}$ and $\mathrm{R}_{2} \mathrm{SnX}_{2}(\mathrm{R}=$ alkyl, aryl; $\mathrm{X}=\mathrm{Cl}, \mathrm{Br}$ ) Organometallics 7388 